\title{
Evidence for designing health promoting pocket parks
}

Peschardt, Karin Kragsig; Stigsdotter, Ulrika K.

Published in:

Archnet-IJAR : International Journal of Architectural Research

Publication date:

2014

Document version

Publisher's PDF, also known as Version of record

Citation for published version (APA):

Peschardt, K. K., \& Stigsdotter, U. K. (2014). Evidence for designing health promoting pocket parks. ArchnetIJAR : International Journal of Architectural Research, 8(3), 149-164. 


\title{
EVIDENCE FOR DESIGNING HEALTH PROMOTING POCKET PARKS
}

\author{
Karin Kragsig Peschardt \\ Division of Landscape Architecture and Planning, \\ Department of Geosciences and Natural Resource Management, \\ University of Copenhagen \\ peschardt81@gmail.com \\ Ulrika Karlsson Stigsdotter \\ Division of Landscape Architecture and Planning, \\ Department of Geosciences and Natural Resource Management, \\ University of Copenhagen \\ UKS@ign.ku.dk
}

\begin{abstract}
The use of urban green environments has repeatedly been associated with improved health and well-being for people living in cities. This study focuses on the health promoting potential of pocket parks in the dense city area of Copenhagen. A natural experiment was conducted, which evaluated one pocket park, Dantes Plads, before and after a redesign. Six people were interviewed about their perception of the change. First of all, the results show that Dantes Plads is primarily used for 'rest and restitution'. Furthermore, the interviewees prefer to have the presence of sun, shade and planting in relation to rest and restitution, while varied 'terrain' may create fascination thereby providing the opportunity for restoration. 'Noise level' is perceived differently from subject to subject, while 'benches' as well as 'visual angels' should not be oriented directly towards disturbing surroundings. The findings add to existing knowledge on the design of health promoting pocket parks for 'rest and restitution' in dense city areas.
\end{abstract}

Keywords: Pocket park; Redesign; Evaluation; Perception; Design

\section{INTRODUCTION}

Increased urbanization and densification is a wide spread tendency in cities and the people who live in such areas often have stressful working lives, which may lead to a number of stress related lifestyle diseases (Mitchell \& Popham, 2008). Frequent exposure to green environments has been found to be of crucial importance in relation to the prevention of such lifestyle diseases, as they support psychological restoration (e.g. Kaplan, 1995; Hartig, Evans, Jamner, Davis, \& Gärling, 2003). However, the densification tendency in cities has resulted in a decrease in the amount of green outdoor environments (James et al., 2009). In order to ensure that the urban green environments that do exist in the densest part of the cities support health promoting use, it is important to understand the specific functions they fulfil in relation to people's daily needs, wishes and expectations regarding exposure to outdoor environments. According to Attention Restoration Theory $(A R T)$, the relationship between human beings, nature and urban areas has been described from a cognitive perspective (Kaplan, 1995). The theory suggests that humans have two types of attention; directed attention and soft fascination. Directed attention is used when we have to concentrate on important things. In this process, we have to sort out distracting things, which demand much effort and which over time can cause mental fatigue. To recover our directed attention, we need to stimulate our soft fascination. According to $A R T$ theory, humans have adapted to nature as a species and therefore perceive nature as potential areas to achieve soft fascination, which thereby prevents mental fatigue (Kaplan, 1995). According to the WHO

Archnet-IJAR, Volume 8- Issue 3 - November 2014 - (149-164) - Original Research Articles 
(2011), the definition of mental health is: '..a state of well-being in which every individual realizes his or her own potential, can cope with the normal stresses of life, can work productively and fruitfully, and is able to make a contribution to her or his community'. A large body of evidence points towards natural environments as providing opportunities for restoration and thereby supporting psychological well-being (e.g. Stigsdotter et al., 2010; van den Berg, Maas, Verheij, \& Groenewegen, 2010; Grahn \& Stigsdotter, 2010). However, much of the existing research refers to larger urban green spaces. From a planning perspective, research may now be taken one step further towards understanding the relationship between human health and the environments that constitute the primary outdoor spaces for urban dwellers, which are often smaller green environments such as pocket parks. Within the field of landscape architecture, the process of evidence based health design (EBHD) has been used to concretise how we can design our environments in order to support specific expectations, needs and wishes of the users of the urban green environments. Such a process combines aesthetic and practical landscape architectural skills and experiences, users' special needs, wishes and preferences, research evidence and valid practical experience (Lygum, Stigsdotter, Konijnendijk, \& Højbjerg, 2013). This paper makes a contribution to the EBHD process by providing research evidence on the health promoting design of pocket parks.

One type of urban green environment is pocket parks, which may be seen as health promoting units which act as stepping stones between larger urban green spaces (Thwaites, Helleur, \& Simkins, 2005; Forsyth \& Musacchio, 2005; Peschardt, Schipperijn, \& Stigsdotter, 2012) and thereby fulfill more immediate needs for green outdoor exposure. Today, there is an emerging tendency which points towards evidence based knowledge on the specific use and design of pocket parks (Nordh, Hartig, Hagerhall, \& Fry, 2009; Nordh, 2010; Nordh \& Østby, 2013; Peschardt et al., 2012; Peschardt \& Stigsdotter, 2013). In a study by Peschardt et al. (2012; 2014), 686 respondents in nine pocket parks in Copenhagen were asked about their preferred use. The results showed that 'socializing' (meeting for social purposes) and 'rest and restitution' (restoring from mental fatigue) were the primary reasons for use. Generally people who socialize in pocket parks stay in the areas for $30-120$ minutes whereas those who use the areas for rest and restitution stay in the areas for $15-30$ minutes. In the same study, physical features such as 'green ground-cover', 'eye-level greenery' and 'tree canopy', 'size', 'physical content' (e.g. benches, tables, path systems, presence of cafe) and the influence of 'noise levels' and 'view outside the park' were investigated. In relation to 'socialising,' features which promote gathering (such as 'tables', 'benches' and 'cafes') were preferred, whereas green features (such as 'flowerbeds', 'green ground cover' and 'eye-level greenery) should be avoided. 'Green ground cover' and 'enclosed niches' promoted 'rest and restitution,' which is supported by Nordh \& Østby (2013) who suggest that 'trees', 'grass' and 'bushes' are positive predictors for restoration. Disturbing features such as 'high noise levels', 'playgrounds', 'view outside the park' and features promoting gathering should be avoided in relation to 'rest and restitution' (Peschardt, Stigsdotter, \& Schipperijn, 2014). However, not only has the actual design had an influence on use, as the subjective perception of a place can also influence the way users perceive certain environments (Gehl, 2003; Francis, 2003; Forsyth \& Musacchio, 2005). In addition, the specific characteristics may influence the subjective perception positively and thereby provide a sense of place attachment (Madden, 2008), which refers to the bonding between a physical environment and the user (Proshansky, 1978).

In 2009, the City of Copenhagen introduced their 'Pocket Park Program' (City of Copenhagen, 2009), the purpose of which was to increase the provision of pocket parks with 14 new areas before 2015. At the time of writing, five had been established, one of which is Dantes Plads which was redesigned in 2010/2011. Dantes Plads therefore provided the unique opportunity to investigate the design and use of a pocket park in the densest part of Copenhagen before and after a redesign. We hypothesize that local users of Dantes Plads may contribute 
valuable information on how the design of pocket parks best meets user needs. We therefore pose the following research questions:

- Who used Dantes Plads before and after the redesign and how?

- How did the users perceive the design before and after the redesign?

\section{METHODS}

\section{Analysis Of Dantes Plads Before The Redesign}

Before the redesign of Dantes Plads, the area was split into two zones; one for parking, and one for recreational use. The part of Dantes Plads that could be used for recreational purposes was a rectangular area of $932 \mathrm{~m}^{2}$ facing $\mathrm{H}$. C. Andersen's Boulevard, which is heavy trafficked and has a significant influence on the area. In the rather small rectangular area, there was no variation in the terrain. The paved area constituted the primary place where people could use the benches or could stop and look at the historical building 'Glyptoteket' (art museum) on the other side of the road. The lawn, which the users could walk on and use (lying, sitting), functioned as a secondary area. The path towards the road was the primary passage along which people walked. Minor paths which crossed the area on each side functioned as transit paths. The area was defined by edges created by the buildings which faced the area. A smaller edge seperated the green area from the parking area. The paved area was furnished with flowerpots and benches which functioned as places where people could take a break when passing the area. The benches were placed facing the hardscape surface of the area meaning that users had the green features behind them. There was nowhere to sit in the shade. The green area consisted of a lawn, flowerbeds and bushes. There was no distinct lighting in the area.

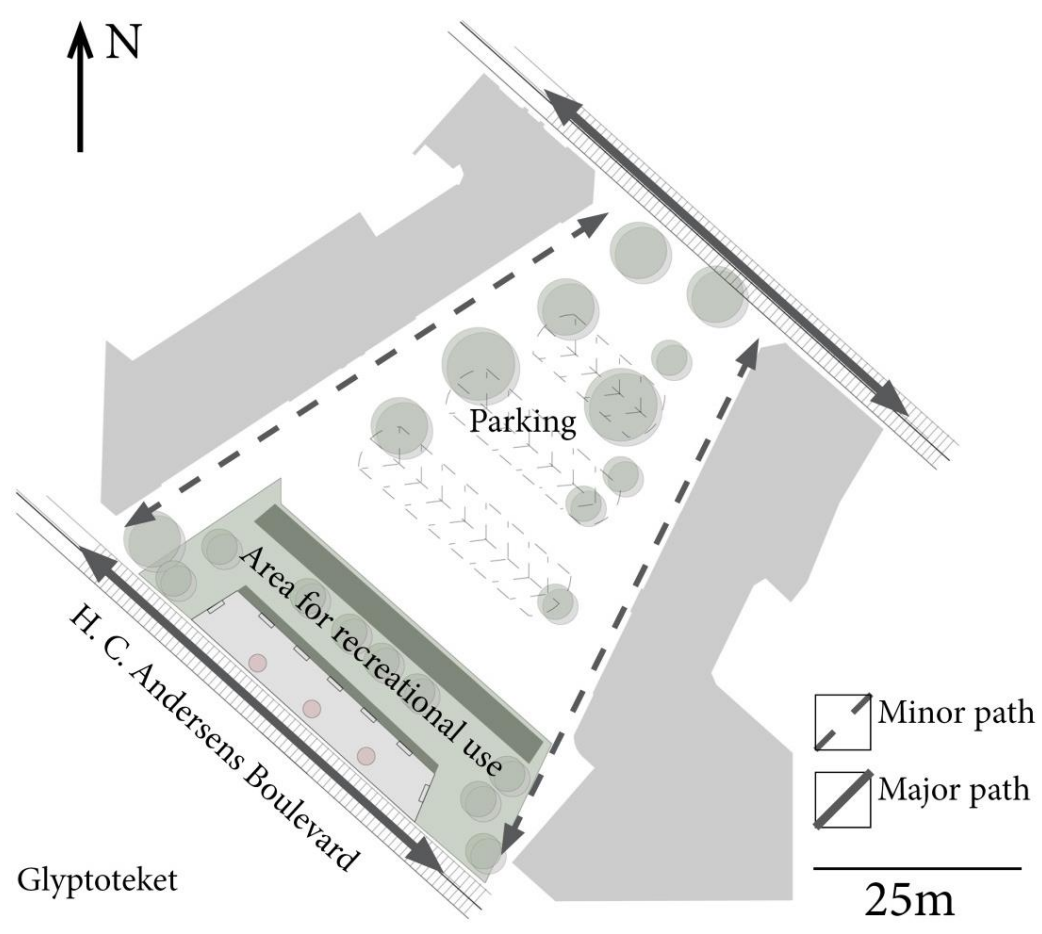

Figure 1: Dates Plads before the redesign (Source: Authors). 


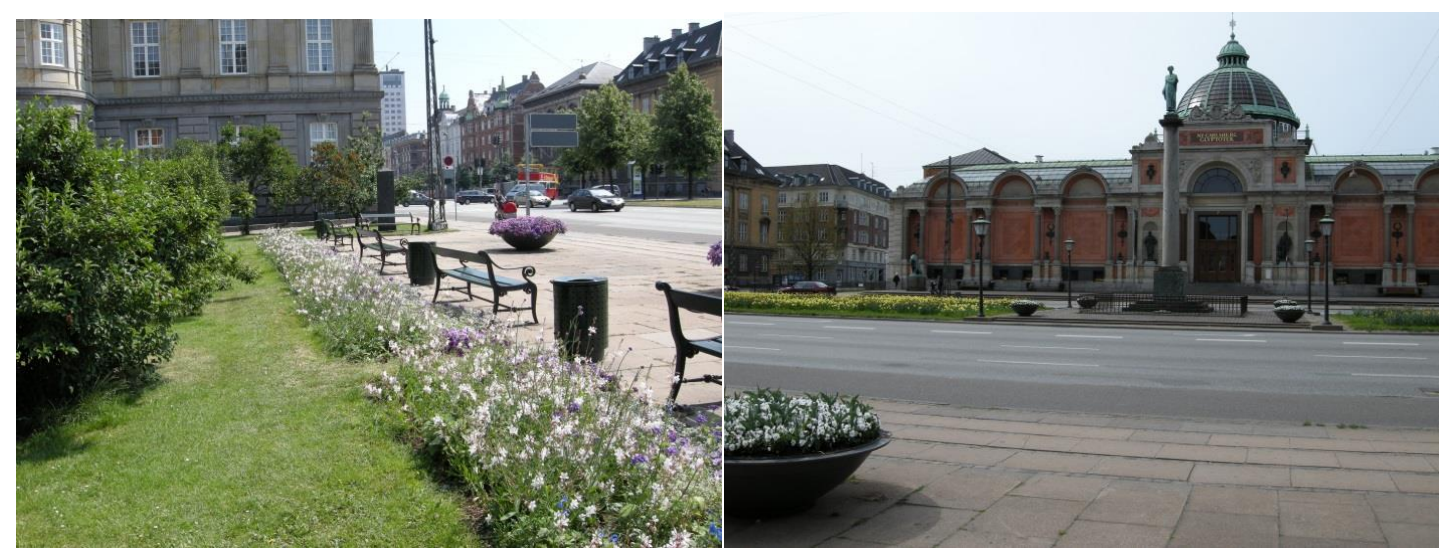

Figure 2 and 3: Photos of Dantes Plads before the redesign (Source: KKP)

\section{Intentions With The New Design Of Dantes Plads}

Dantes Plads was redesigned by GHB Landscape architects in cooperation with COBE architects and the consultancy company Grontmij. One of the core issues in the program for the future design of Dantes Plads was to maintain the number of parking spaces. Furthermore, it was a great wish to maintain the culture-axis which goes from the parliament building 'Christiansborg' to the 'Meat Packing District' (see figure 4). As far as possible, the architects wanted to save the existing trees while the geometry, colors and materials used had to relate to Glyptoteket (a museum with a collection of sculptures, see figure 3), which is the primary relation to Dantes Plads (Weeke Borup, 2014). The intention was to create a green space with a large variety of planting for the whole year. It had to be possible to sit in the sun and shade on traditional benches placed in the area. Natural walking lines had to ensure that the whole area would be used. The variation in the terrain had to provide secondary places to sit, lie, play or run. The waving terrain had to direct focus away from the parking spaces without making a dominant border between the two functions (Weeke Borup, 2014).

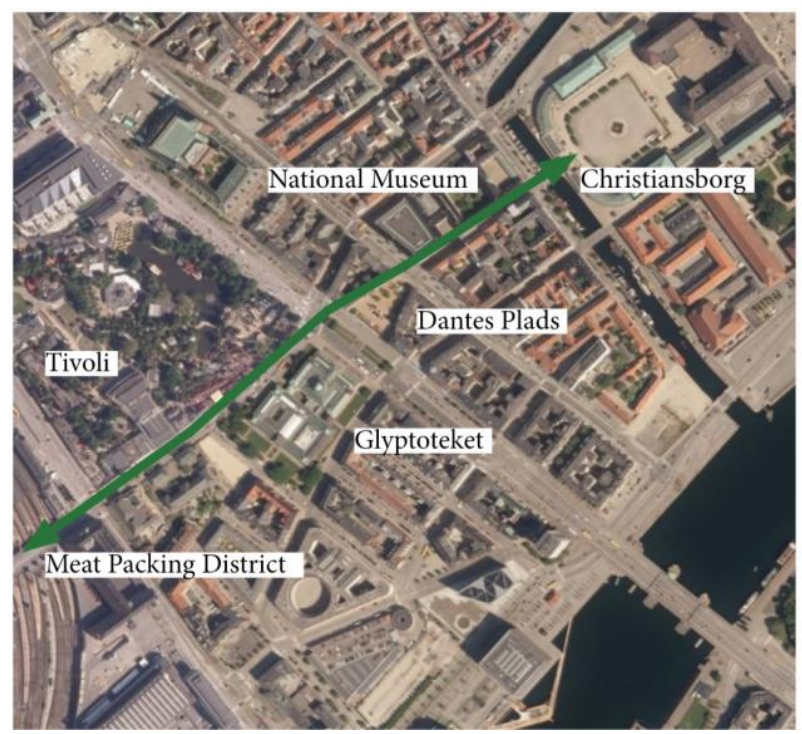

Figure 4: The green line indicating the 'Culture axis' from 'Christiansborg' to the 'Meat Packing District' (Source: Authors). 


\section{Analysis Of Dantes Plads After The Redesign}

After the redesign, the parking spaces have been integrated in the area. Dantes Plads is still influenced by 'Glyptoteket' and H.C. Andersens Boulevard. The area furthest away from the road constitutes the primary area where there are several opportunities to sit. The area closest to the road includes the parking spaces and is a secondary space. The major paths pass the area on each side beside the roads, while minor paths run along-side the buildings and across the area. The buildings constitute the edges and influence the experience of Dantes Plads. The benches in the middle of the area face the area itself. The surface create connections between the area and 'Glyptoteket' and is raised-up in certain places to form wave shapes which create sloping surfaces at various angles. The edges of the 'waves' create spaces for sitting, lying and playing. Towards H. C. Andersen's boulevard, long narrow flowerbeds create an edge between the parked cars and the sidewalk. There are planting beds with trees and flowers which provide opportunities for sitting in the shade. Paving stone lights have been added in the surface which accentuate the variation in terrain.

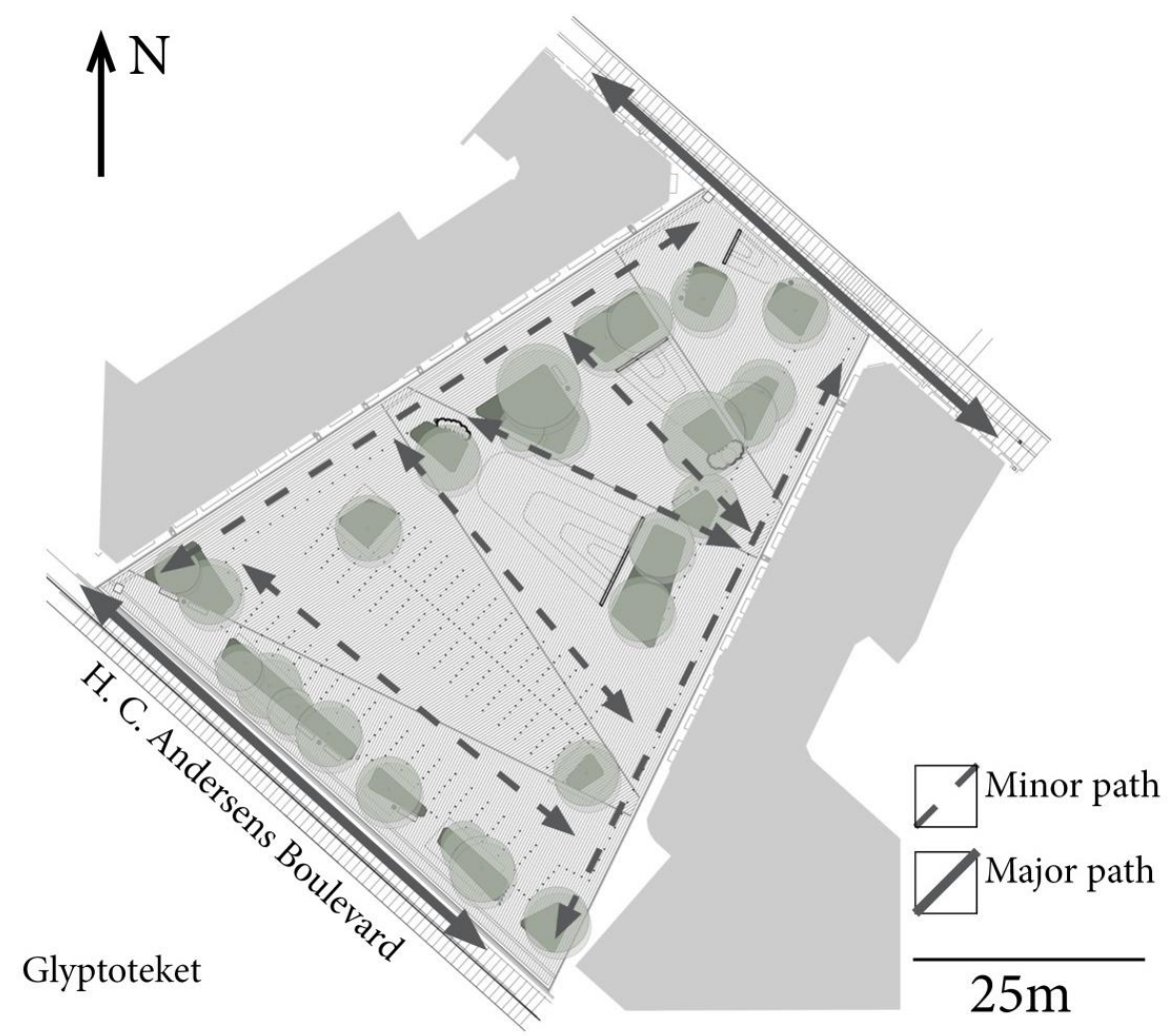

Figure 5: Dates Plads after the redesign (illustration modified (Source: Weeke Borup, 2014). 

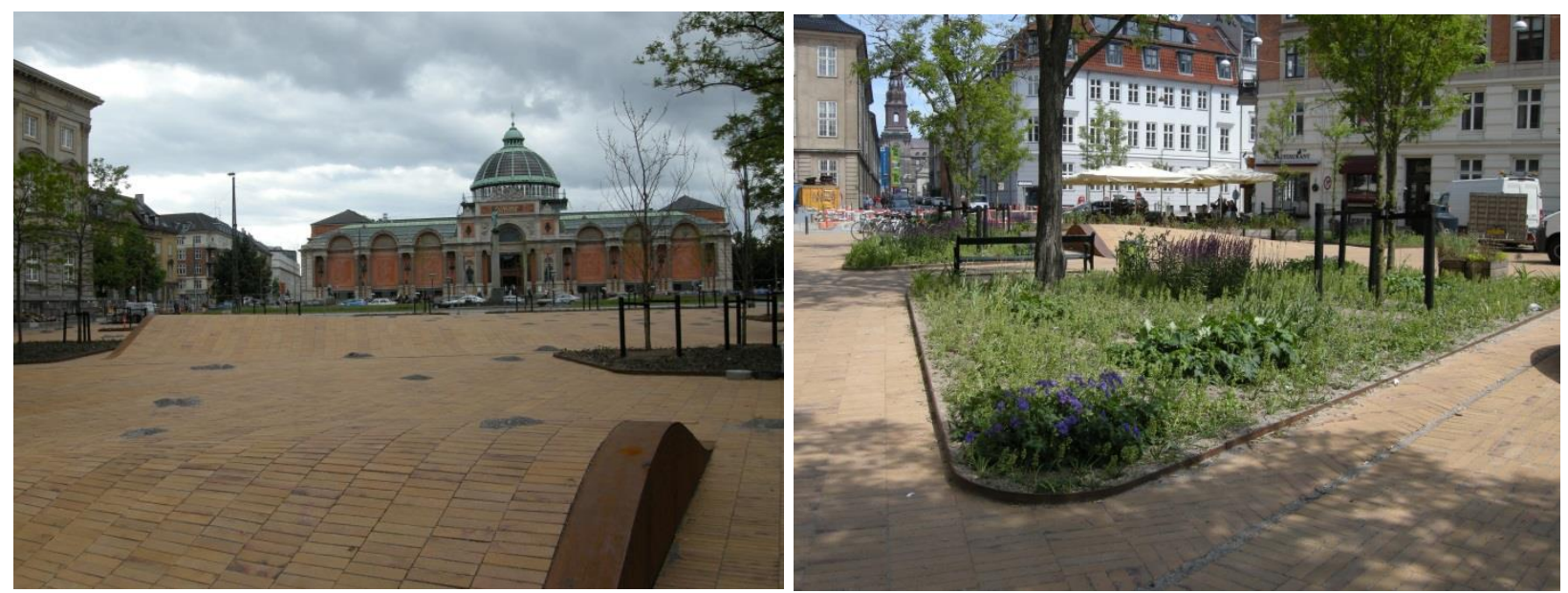

Figure 6 and 7: Dates Plads after the redesign (Photos KKP).

\section{Data Collection}

This study investigated Dantes Plads pre and post a redesign. The time periods for the data collection were April till October 2010 and summer 2012. The summer months were chosen as the weather is best during those months which moreover most likely would increase the number of visitors in the pocket park. Questionnaires were handed out at both time periods to people using the area for a longer or shorter stay, which means that people who were just walking past the area were not included. In 2010, data were collected in the mornings, middays, evenings and in weekends in order to reach as many different users as possible. Due to time constraints, we calculated the peak periods for responses for the data collection in 2010 and decided to focus on these periods for the data collection in 2012. The questions included in this study concerned reasons for use, and the questions were: 'Why did you come here?' for which the possible answers were, 'to socialise', 'Passage', 'to walk the dog' and 'Rest and restitution'. Additionally, 'Other' was included whereby respondents could state another reason for visiting the area. Questions regarding demographic background (age, gender, education, nationality) were also posed. The questionnaires used in 2010 and 2012 were identical apart from the followingtwo questions which were added to the 2012 version: 'Did you use this area before the redesign?' and 'If yes, what did you use it for?'

\section{Interviews}

In addition to the questionnaire survey, in 2012, 6 interviews were conducted with respondents who answered that they had known Dantes Plads before the redesign. Based on experience from data collection in 2010 it was decided not to conduct interviews on rainy days as hardly any visitors would be present. The interview was semi-structured allowing the questions posed by the interviewer to differ slightly from the interview guide. However, the same themes were discussed with all interviewees (Bryman Alan, 2008). In general, not many approached respondents wished to participate in the interviews and those who did, did not have much time so each interview lasted for approx. 5-7 minutes. The questions asked are presented in Table 1.

The interviews were transcribed and analyzed. The analysis focused on the themes addressed in the interviews about use, as well as perception of the design and the proximity to the road before and after the redesign. SPSS version 20 was used to analyze the general use and the demographic background of the users. 
Table 1: The questions included in the semi-structured interviews.

\begin{tabular}{|l|l|}
\hline Number & Question \\
\hline Q1 & 'Do you use Dantes Plads differently today than before the re-design?' \\
\hline $\mathbf{Q} 2$ & 'Can you see that changes have been made to the area?' \\
\hline $\mathbf{Q 3}$ & 'Are there any specific features in the new design of Dantes Plads that you notice?' \\
\hline $\mathbf{Q} 4$ & 'How do these changes influence your experience of Dantes Plads?' \\
\hline $\mathbf{Q 5}$ & 'In this relation, which parts of Dantes Plads meet your needs the best?' \\
\hline $\mathbf{Q 6}$ & 'Are there any special reasons why you visit Dantes Plads?' \\
\hline $\mathbf{Q 7}$ & $\begin{array}{l}\text { 'Does the big road next to the pocket park have an influence on your experience of Dantes } \\
\text { Plads?' }\end{array}$ \\
\hline Q8 & 'What influence did the road have on your experience before the redesign?' \\
\hline
\end{tabular}

\section{RESULTS}

\section{The Demographic Background And The Reasons For Use}

Initially, the users of Dantes Plads and how they used the area were investigated before and after the redesign. As presented in table 2, slightly more men were among the users after the redesign. Furthermore, the distribution of the users in relation to education has changed. After the redesign, the majority of users were highly educated (more than 15 years), while before the redesign users with 10 to 15 years of education were observed using it the most. With regards to reasons for visiting Dantes Plads, the majority stated that the main reason was 'rest and restitution' both before $(35 \%)$ and after $(40 \%)$ the redesign. 'Other' $(40 \%)$ is equal both before and after the redesign. The majority of people visited Dantes Plads 'less than once a month' or for the 'first time' both before (65\%) and after (56\%) the redesign. However, quite a few people also visited Dantes Plads several times a week before (19\%) and after (22\%).

Table 2: Demographic background of respondents and use before and after the redesign of Dantes Plads. The figures highlighted in bold are those that differ noticeably from before and after.

\begin{tabular}{|c|c|c|}
\hline $\begin{array}{c}\text { Total population (15-100 } \\
\text { years) }\end{array}$ & $\begin{array}{c}\text { Before } \\
(\mathbf{\%})\end{array}$ & After (\%) \\
\hline Gender & $\mathbf{n = 4 8}$ & $\mathbf{n = 4 5}$ \\
\hline Male (15-100) & 52 & $\mathbf{6 0}$ \\
\hline Nationality & & \\
\hline Danish & 88 & 96 \\
\hline Education & & \\
\hline$<10$ years & 21 & 9 \\
\hline $10-15$ years & $\mathbf{4 8}$ & 29 \\
\hline$>15$ years & 35 & $\mathbf{5 3}$ \\
\hline Age & & \\
\hline $15-29$ & 13 & 24 \\
\hline $30-49$ & 40 & 36 \\
\hline $50-65$ & 35 & 27 \\
\hline $66-100$ & 10 & 11 \\
\hline Reasons for visit & & \\
\hline Socialising & 8 & 4 \\
\hline
\end{tabular}




\section{ArchNet}

\begin{tabular}{|c|c|c|} 
Passage & 31 & 18 \\
\hline Walking the dog & 4 & 0 \\
\hline Rest and Restitution & 35 & $\mathbf{4 0}$ \\
\hline Other & 25 & $\mathbf{4 0}$ \\
\hline How often do you come here? & & \\
\hline Several times a week & 19 & 22 \\
\hline Once a week & 8 & 2 \\
\hline Several times a month & 4 & 11 \\
\hline Once a month & 4 & 9 \\
\hline Rarer & 27 & 20 \\
\hline First time & 38 & 36 \\
\hline
\end{tabular}

\section{The Six Interviewees}

In total, six people agreed to be interviewed, henceforth referred to as $R 1-R 6$. All answered that they knew the area before the redesign. In the following table 3 , the six interviewees are presented.

Table 3: The six interviewees.

\begin{tabular}{|l|l|l|l|l|}
\hline Gender & Code & Age & Education & Reason for visit \\
\hline Man & R1 & 42 & $>15$ years & Passage \\
\hline Man & R2 & 48 & $>15$ years & Rest and restitution \\
\hline Man & R3 & 65 & $<10$ years & Work \\
\hline Man & R4 & 28 & $10-15$ years & Study \\
\hline Woman & R5 & 57 & $10-15$ years & Smoking break \\
\hline Man & R6 & 51 & $>15$ years & Passage \\
\hline
\end{tabular}

In the following tables $4-8$ the responses to the questions (Q1 - Q8) are presented in five categories. 


\section{Category 1: Reason for using Dantes Plads (Q6)}

Table 4: Responses to the question constituting category 1: Reason for using Dantes Plads.

\begin{tabular}{|c|c|c|}
\hline \multicolumn{3}{|c|}{ Category 1: Reason for using Dantes Plads (Q6) } \\
\hline $\begin{array}{l}\text { Two respondents answered } \\
\text { that they were using the } \\
\text { area for 'passage' }\end{array}$ & $\begin{array}{l}\text { One respondent (R5) } \\
\text { answered that she was us- } \\
\text { ing the area for a smoking } \\
\text { break from work }\end{array}$ & $\begin{array}{l}\text { The student (R4) who also } \\
\text { used the area before the } \\
\text { redesign said }\end{array}$ \\
\hline $\begin{array}{l}(\mathrm{R} 6))^{\prime} \cdot . . \text { a small break in } \\
\text { order to prepare for a meet- } \\
\text { ing. Charge the batteries'. } \\
\text { (R1:) '... before it was just a } \\
\text { passage, now there is this } \\
\text { bench and now I can sit } \\
\text { a bit more peacefully and } \\
\text { quietly. }\end{array}$ & $\begin{array}{l}\text { (R5): 'Now I can sit out } \\
\text { here quietly and peacefully } \\
\text { and just get five minutes } \\
\text { break before I have to go } \\
\text { up again, right' }\end{array}$ & $\begin{array}{l}\text { (R4): 'I read in the early } \\
\text { mornings, mainly week- } \\
\text { ends after being at the li- } \\
\text { brary and then ride my bike } \\
\text { here and sit if there are } \\
\text { spare seats and read half } \\
\text { an hour to forty five min- } \\
\text { utes before leaving again' }\end{array}$ \\
\hline
\end{tabular}

Even though only one respondent said that he used the area for 'rest and restitution', the activities performed by those who answered 'passage' or 'other' are still quiet activities which may be in line with 'rest and restitution'.

\section{Category 2 (Q1): Experience of design before the redesign}

Table 5: Responses to the question constituting category 2: Experience of design before the redesign.

Category 2 (Q1): Experience of design before the redesign

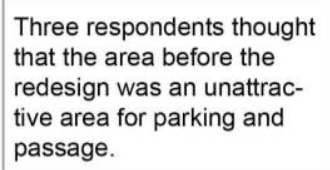

Three respondents thought that the area before the

redesign was an unattrac-

tive area for parking and

passage.

(R1): 'Before it was a
passage...... I didn't think it
was interesting....'
(R2): '.... before it was just a
flat piece of ground....it was
designed to be some kind
of parking area...'.
(R5): '... it was always
some social misfits who sat
there it wasn't very attrac-
tive....

Three of the respondents were positive about the previous design of the area.

(R3): 'It was nice, but in a completely different way which cannot be compared'.

(R6): 'I have been doing fine here in both contexts'.

(R4): '...I use it to read in the early mornings'.

\section{Category 3 (Q2-Q5): Experience of Dantes Plads after the redesign}


Table 6: Responses to the questions constituting category 3: Experience of Dantes Plads after the redesign.

Category 3 (Q2-Q5): Experience of Dantes Plads after the redesign

A number of the respondents especially noticed the sun, light and shelter

R1): '.... and the sun, it's usually here in the morning'.

(R6):'...the light is a bonus, that's what I notice' and '.... I sit where the sun is' and 'I think it was nice before but judged on the light I think this is better'.

(R4):'...you can sit where the trees create shadow and shelter but also if you want sun you can sit where the sun is shining upon you' and ...' You could also do that before, but I wouldn't say that you could where there was good shelter and shade before... it was kind of moved towards Tivoli (amusement park) and the road and you would sit and look at the traffic most of the time'.
More specific comments about the terrain, planting (trees/life, fauna) and furniture:

(R1): 'No I didn't'... (use the benches before the redesign) now there is this bench and you can sit a little more undisturbed in peace and quiet. But you still have H.C. Andersen's boulevard rumbling by' and 'What I notice now is those 'mountains' in the middle and the flowerbed'....

(R4): 'The raised terrain...that's very characteristic for this little pocket park. The tile surface is also new and the planting...the planting is definitely defining the space and you can sit different places and see different things' and 'It means a lot to me that the landscape has been used as a theme and that the area changes over the day in relation to the sun and in the evening when the lights are turned on in this varying plateau'.

(R5): '.. It (the planting) creates life for insects and birds, it creates shadow if one wants that, and it creates shelter when they grow a bit bigger right. In total it gives a lighter character to the place'.

(R6): 'It has become well-arranged, it is more tidied up without being too much and completely stringent. I like the variations here. Compared to earlier I think it has been opened up and become lighter'. 


\section{ArchNet $\Gamma$}

\section{Category 4 (Q4): Proximity to workplace as a positive thing for both companies and for employees}

Table 7: Responses to the question constituting category 4: Proximity to workplace as a positive thing for both companies and for employees.

Category 4 (Q4): Proximity to workplace as a positive thing for both companies and for employees

One respondent who worked for a travel agency with a view to Dantes Plads mentioned

(R2)'...now it has become an urban space and that has been an argument for placing our company here'. Another respondent also working close to Dantes Plads answered to the question: Do you use it in breaks to go out and sit? '...Yes we do that's definite...'
Another respondent also working close to Dantes

Plads answered to the question: Do you use it in breaks to go out and sit?

\begin{tabular}{|l|}
\hline '...Yes we do that's defi- \\
nite...' (R4). \\
\end{tabular}

Another two mentioned: breaks to go out and sit?

mall break in order to prepare for a meeting. Charge the batteries' (R6),

'Now I can sit out here quiet and peaceful and just get five minutes break before I have to go up again, right' (R5). 


\section{Category 5 (Q7-Q8): Proximity to road}

Table 8: Responses to the questions constituting category 5: Proximity to road.

Category 5 (Q7-Q8): Proximity to road

The interviewees reported what they thought about the closeness of the large road. Their opinions can be categorized as split.

(R1): 'I did not think it was interesting before, it was the road. Now you can be here and sit in the middle. And that means that you can get a little away from the road'...'there is still a lot of noise though, but I guess you cannot avoid that in the middle of Copenhagen'

(R2): ...to us (the company) it has had a positive influence in that we chose a situation where we get more exposed to passing traffic, so in that relation it has been positive. Otherwise there is not much positive to say about traffic'.

(R3):'... its very interesting to see all the passing cars..' on the contrary 'you can see the cars better now, it seems more negative now than before'.

(R4): '...Sometimes it can have an almost calming effect that there is traffic with a monotonous noise level repeating itself. Then I know it is there and then I can more easily exclude it, whereas if I hear only a few cars then it would be more difficult to exclude them' and I am prepared for it, I know I am not entering a forest or a park for instance...'.

(R5): '... we need some cars' and 'I can easily distance myself from that noise'.

(R6): '...The road is disturbing, that's the only thing that's a shame, I would have taken all the cars away'.

\section{DISCUSSION}

\section{The Users And Their Use Of Dantes Plads Before And After The Redesign}

The demographic background of the users of Dantes Plads changed slightly after the redesign compared to before. The increase in the number of men, people aged (15-29) and highly educated could be a chance finding due to the low number of respondents. However, previous studies have also found that highly educated people seem to use UGS frequently (Yilmaz, Zengin, \& Yildiz, 2007; Peschardt et al., 2012; Schipperijn, Stigsdotter, Randrup, \& Troelsen, 2010). It may also be that the new design has attracted new companies to the area as explained 
by (R2) so that the employees use the area, thereby resulting in a change in the user composition. A number of the interviewees were using Dantes Plads because the area was close to their work or as a break from travelling from one place to another. This also emphasizes the high need for a restorative experience in relation to a busy working life (Peschardt et al., 2012). This finding is also in line with previous research on the importance of green environments in relation to workplaces (Lottrup, Stigsdotter, Meilby, \& Corazon, 2012). 'Rest and restitution' is the primary use both before and after the redesign. And the number of users using Dantes Plads for 'socializing' seems to be quite low compared to previous findings on the primary types of use of pocket parks (Peschardt et al., 2012). The fact that Dantes Plads does not include many opportunities for gathering may explain this finding.

\section{The Perception Of The Design Before And After The Redesign}

Generally, the new design seems to be perceived more positively than the old design. In fact some of the interviewees did not really recognize the area as a small urban park before the redesign. A reason for this could be due to the very limited area that was suitable for recreational use, which moreover faced the heavy trafficked road. The remaining part was a parking lot which did not invite people to sit or use it for other reasons. Those positive about the old design may have perceived Dantes Plads as a nice green space where they could take a break.

For the interviewees for whom 'rest and restitution' was the main reason for use, the results show that the experience and the variation in the new design in terms of 'terrain', 'planting', 'sun/shade' and 'surface cover' were positively received.

Originally, the architects' intention was that Dantes Plads should have a green appearance (Weeke Borup, 2014) and the fact that a number of the interviewees specifically mentioned the planting as being something special could indicate that the architects' original intentions have been realized. Furthermore, findings from previous studies indicate that the presence of greenery is positively related to the use; 'rest and restitution' in pocket parks (Nordh \& Østby, 2013; Peschardt et al., 2014). This relation furthermore support the attention restoration theory suggesting how natural surroundings can support soft fascination (Kaplan 1995). As the planting and the variation in the terrain was specifically mentioned several times, one may argue that such features create 'fascination' which according to Kaplan (1995) is one of the four characteristics that should be present in a restorative environment. Though it was not a deliberate intention, it seems that the architects have managed to create a design that provides fascinating stimuli and thereby an area that has restorative potential.

The positive comments on the experience of sun and shade firstly confirm that the intention to provide such experiences from the architect has been realized. However, it is important to mention that one could also sit in the sun before the redesign, although the respondents that did so said that it was a completely different experience. The positive feeling related to sun and shade seems to be a general basic need for people using outdoor spaces (Gehl, 2010; Whyte, 1980). According to Whyte (1980 p. 42) 'the best time to sit beneath a tree is when there is sunlight to be shaded from'.

The perception of the 'noise level' differed between the interviewees. Two respondents indicated that they accepted the cars and found the 'noise level' even calming, whereas some of the respondents perceived the 'noise level' negatively or seemed to be very split about the proximity of the road. The interviewees most disturbed by the road was also those with the highest education, which is supported by earlier research by Yu \& Kang (2010) who investigated sound preference compared to education level. In their study, they found that a preference for natural sounds increases with higher education level (Yu \& Kang, 2010).

The change of orientation away from the road allows people to sit more undisturbed and distanced from the traffic, a finding that is also supported by previous studies which suggest that disturbing surroundings should be avoided (Nordh \& Østby, 2013; Peschardt et al., 2014). 
Furthermore, $A R T$ suggests that people need to distance themselves from disturbance in order to restore from mental fatigue (Kaplan, 1995), which is supported by this finding. The fact that some interviewees were positive towards the 'noise level' at Dantes Plads could be explained by another study by Yang \& Kang (2005) who found that the preference for a certain soundscape influenced the choice of which urban square to use. In this respect, some might simply avoid using Dantes Plads, whereas others are prepared for the noise level and find it even 'calming' or 'interesting'. Others again might be disturbed by the noise, but may still use the area as they accept the fact that the area is dominated by traffic.

Some people may also feel some kind of bonding to Dantes Plads which might be another explanation as to why they can abstract from disturbing features. A number of the respondents indicate that they like the area and that they can get an experience which is compatible with what they expect. 'Compatibility' is also one of the four characteristics of a restorative environment (Kaplan, 1995), and if Dantes Plads supports users' expectations, their general perception of the area may be more positive, thereby providing a feeling of place attachment (Madden, 2008; Proshansky, 1978).

Generally, the intentions of the architect have been fulfilled and seem to be noticed by the users of Dantes Plads. A green appearance, opportunities to sit in the sun and shade and variation in the terrain that created secondary seating where among the intentions, all of which were positively mentioned by the interviewees. Furthermore, the high preference for greenery also supports previous findings of features supporting 'rest and restitution' (Peschardt et al., 2014).

\section{Implications for practice}

This present study, adds to the research on design in relation to 'rest and restitution' one of the health promoting uses of pocket parks. A variation in design (terrain, planting, surface cover), as well as opportunities for sitting in the sun or shade are important subjective evaluations to consider when designing a pocket park. Furthermore, the design, as well as the design features, should, as far as possible, be orientated away from noise sources. For a landscape architect, it is a challenge to design a pocket park that meets people's expectations, although in an urban context, users seem to be aware that they are not going to have a forest-like experience due to the restricted space available. And in this regard, the value of the feeling of belonging to a certain environment should not be underestimated. The findings from this case study can contribute with increased knowledge to future EBHD processes for health promoting pocket parks, however further research is needed in order to reach at more concrete conclusions useful for practitioners.

\section{Discussion of Methodology}

This case study is based on data collected over two periods of time. This is a strength, as on-site evaluations capture contextual influence when users evaluate an area. The study was a unique chance to investigate a design before and after a redesign, and the design of the study was therefore conducted with the limitations it provided. The interviews were designed based on previous experiences of onsite data collection in pocket parks. First of all the questions were prepared and second they should not take too long. A greater number of respondents and interviewees would have improved the validity of the conclusions reached based on the findings, although the qualitative approach does add valuable information that would not have been possible to obtain from a questionnaire survey. Furthermore, the inclusion of the intentions of the old design could have contributed to a better understanding of Dantes Plads before the redesign. This qualitative approach contributes to the existing research on the features which support the health promoting use of pocket parks. 


\section{CONCLUSION}

The results from this study show that the subjective perception of the design of a pocket park may also add valuable knowledge when trying to define a design which supports the most preferred activities in pocket parks. In this case, 'rest and restitution' was the primary reason for using Dantes Plads, and thus the findings are related to this purpose of use. With this study, landscape architects can improve their knowledge on how to design pocket parks to improve health in dense cities. The study should be seen as a contribution to the field of landscape architecture with further research that can be used to improve future evidence based health design processes for health promoting pocket parks.

\section{REFERENCES}

Bryman Alan (2008). Social research methods. (Third ed.) London: Oxford university Press.

City of Copenhagen (2009). Lommeparker, Træer og andet grønt (Pocket Parks, Trees and other green elements) Retrieved December 1st, 2010 from http://www.kk.dk/Borger/ByOgTrafik/GroenneOmraader/Storbyhaver/ /media/7F9CA219325949D C9351D180ABAC3F36.ashx. [in Danish].

Forsyth, A. \& Musacchio, L. (2005). Designing Small Parks: A Manual Adressing Social and Ecological Concerns. New York: Wiley.

Francis, M. (2003). Urban Open space, Designing for user needs. Washington: Island Press.

Gehl, J. (2003). Life Between buildings. (5 ed.) (vols. 1) Copenhagen: The Danish Architectural Press.

Gehl, J. (2010). Byer for mennesker. (1. udgave, 1. oplag ed.) Copenhagen: Jan Gehl og Bogværket.

Grahn, P. \& Stigsdotter, U. K. (2010). The relation between perceived sensory dimensions of urban green space and stress restoration. Landscape and Urban Planning, 94, 264-275.

Hartig, T., Evans, G. W., Jamner, L. D., Davis, D. S., \& Gärling, T. (2003). Tracking restoration in natural and urban field settings. Journal of Environmental Psychology, 23, 109-123.

James, P., Tzoulas, K., Adams, M. D., Barber, A., Box, J., Breuste, J. et al. (2009). Towards an integrated understanding of green space in the European built environment. Urban Forestry \& Urban Greening, 8, 65-75.

Kaplan, S. (1995). The restorative benefits of nature: Toward an integrative framework. Journal of Environmental Psychology, 15, 169-182.

Lottrup, L., Stigsdotter, U. K., Meilby, H., \& Corazon, S. S. (2012). Associations between use, activities and characteristics of the outdoor environment at workplaces. Urban Forestry \&amp; Urban Greening, $11,159-168$.

Lygum, V. L., Stigsdotter, U. A., Konijnendijk, C. C., \& Højbjerg, H. (2013). Outdoor environments at Crisis Shelters: User needs and preferences with respect to design and activities. Archnet-IJAR : International Journal of Architectural Research, 7, 21.

Madden, K. (2008). How to Turn a Place Around. A Handbook for Creating succesful Public Spaces. (Wiley-Schwartz, Andy ed.) New York: Project for Public Spaces.

Mitchell, R. \& Popham, F. (2008). Effect of exposure to natural environment on health inequalities: an observational population study. The Lancet, 372, 1655-1660.

Nordh, H. (2010). Restorative components of small urban parks. Ph.D. Thesis, Department of Landscape Architcture and Spatial Planning, Norwegian University of Life Sciences, Aas, Norwegian University of Life Sciences.

Nordh, H., Hartig, T., Hagerhall, C. M., \& Fry, G. (2009). Components of small urban parks that predict the possibility for restoration. Urban Forestry \& Urban Greening, 8, 225-235.

Nordh, H. \& Østby, K. (2013). Pocket parks for people - A study of park design and use. Urban Forestry \& Urban Greening, 12, 12-17.

Peschardt, K., Stigsdotter, U. A., \& Schipperijn, J. (2014). Identifying Features of Pocket Parks that may be related to Health Promoting Use. Landscape Research (in press).

Peschardt, K. K., Schipperijn, J., \& Stigsdotter, U. K. (2012). Use of Small Public Urban Green Spaces (SPUGS). Urban Forestry and Urban Greening, 11, 235-244.

Peschardt, K. K. \& Stigsdotter, U. K. (2013). Associations between park characteristics and perceived restorativeness of small public urban green spaces. Landscape and Urban Planning, 112, 26-39.

Proshansky, H. M. (1978). The City and Self-Identity. Environment and Behavior, 10, 147-169.

Archnet-IJAR, Volume 8- Issue 3 - November 2014 - (149-164) - Original Research Articles 
Schipperijn, J., Stigsdotter, U. K., Randrup, T. B., \& Troelsen, J. (2010). Influences on the use of urban green space - A case study in Odense, Denmark. Urban Forestry \& Urban Greening, 9, 25-32.

Stigsdotter, U. K., Ekholm, O., Schipperijn, J., Toftager, M., Kamper-Jørgensen, F., \& Randrup, T. B. (2010). Health promoting outdoor environments - Associations between green space, and health, health-related quality of life and stress based on a Danish national representative survey. Scandinavian Journal of Public Health, 38, 411-417.

Thwaites, K., Helleur, E., \& Simkins, I. M. (2005). Restorative urban open space: Exploring the spatial configuration of human emotional fulfilment in urban open space. Landscape Research, 30, 525547.

van den Berg, A. E., Maas, J., Verheij, R. A., \& Groenewegen, P. P. (2010). Green space as a buffer between stressful life events and health. Social Science \& Medicine, 70, 1203-1210.

Weeke Borup, M. (7-1-2014). Dantes Plads. 7-1-2014. Ref Type: Personal Communication

WHO (2011). Mental Health: a state of well-being. http://www.who.int/features/factfiles/mental health/en/

Whyte, W. H. (1980). The Social Life of Small Urban Spaces. (Sixth Printing 2009 ed.) New York: Project for Public Spaces.

Yang, W. \& Kang, J. (2005). Soundscape and Sound Preferences in Urban Squares: A Case Study in Sheffield. Journal of Urban Design, 10, 61-80.

Yilmaz, S., Zengin, M., \& Yildiz, N. D. (2007). Determination of user profile at city parks: A sample from Turkey. Building and Environment, 42, 2325-2332.

Yin, R. K. (2009). Case Study Research, Design and methods. (four ed.) California: Sage.

$\mathrm{Yu}, \mathrm{L}$. \& Kang, J. (2010). Factors influencing the sound preference in urban open spaces. Applied Acoustics, 71, 622-633.

\section{AUTHORS}

Karin Kragsig Peschardt

Division of Landscape Architecture and Planning,

University of Copenhagen

peschardt81@gmail.com

\section{Ulrika Karlsson Stigsdotter}

Division of Landscape Architecture and Planning,

University of Copenhagen

UKS@ign.ku.dk 